\title{
Growth and reproductive performance of 14- to 15-month-old Hereford heifers
}

\author{
Carolini Machado Landarin'1, José Fernando Piva Lobato ${ }^{2}$, Adriana Kroef Tarouco ${ }^{3}$, Jaime \\ Urdapilleta Tarouco ${ }^{2}$, Lidiane Raquel Eloy', Luciana Pötter ${ }^{4}$, Antônio Augusto Galarza Rosa ${ }^{1}$
}

\footnotetext{
${ }^{1}$ Universidade Federal do Rio Grande do Sul, Programa de Pós-graduação em Zootecnia, Porto Alegre, RS, Brazil.

2 Universidade Federal do Rio Grande do Sul, Departamento de Zootecnia, Porto Alegre, RS, Brazil.

${ }^{3}$ Fundação Estadual de Pesquisa Agropecuária, Hulha Negra, RS, Brazil.

${ }^{4}$ Universidade Federal de Santa Maria, Departamento de Zootecnia, Santa Maria, RS, Brazil.
}

\begin{abstract}
Aiming at breeding heifers with 14-15 months of age, 100 Hereford calves were subjected to different feeding systems. Heifers grazed on a natural pasture in early winter, fed or not a supplement (14\% crude protein; $72 \%$ total digestible nutrients), were transferred to a ryegrass pasture for 73 days, and then returned to a natural pasture for 15 days until the beginning of the breeding season. During the last 15 days on ryegrass pasture and the 15 days of the return to the natural pasture, half of the heifers of the two previous systems were offered the supplement, thereby establishing four feeding treatments. Heifers supplemented during the second period, independently of supplementation during the first grazing period, presented higher average daily gain and greater backfat values than the non-supplemented heifers. The breeding season extended for 75 days. At the start of the breeding season (November 18), heifers supplemented during both periods presented higher body condition score and body weight. The highest percentage of puberty was determined in heifers supplemented in the early winter. Heifers supplemented during both periods presented the highest pregnancy rate. Pregnant heifers presented higher average daily gain when fed the supplement during the second period, as well as higher relative pelvic area, body weight, and body condition score at the start and end of the breeding season. To an expressive pregnancy in 14- to 15- month-old heifers, higher weaning weights and pasture allowance are required to get a better answer to supplements offered.
\end{abstract}

Key Words: backfat thickness, natural pasture, pelvic area, reproductive tract score, rib eye area, supplementation

\section{Introduction}

The increase in the size of the Brazilian herd in the last 40 years has allowed the continuous increase in beef production. Brazil is the largest global exporter of beef and the domestic market consumes $83 \%$ of the volume produced (Brasil, 2013).

However, research has shown that significant improvements can still be achieved in the average offtake rate obtained in Brazil, which has remained stable at around $21 \%$ in the last few years, as well as in other production and productivity indexes. Pötter et al. (1998) and Beretta et al. (2001) demonstrated that to achieve an offtake rate of $28 \%$, an $80 \%$ weaning rate is required and that heifers need to be bred and steers slaughtered at two years of age. However, offtake rate can be increased up to $35 \%$ when age at first

Received January 14, 2016 and accepted August 21, 2016.

Corresponding author: jose.fernando.lobato@ufrgs.br

http://dx.doi.org/10.1590/S1806-92902016001100005

Copyright (C) 2016 Sociedade Brasileira de Zootecnia. This is an Open Access article distributed under the terms of the Creative Commons Attribution License (http://creativecommons.org/licenses/by/4.0/), which permits unrestricted use, distribution, and reproduction in any medium, provided the original work is properly cited. breeding is reduced to $14-15$ months of age and steers are slaughtered at two years of age.

The productivity indexes of the best Brazilian beef cattle operations are higher than the average, which may allow them to apply to more intensive production systems, including the breeding of heifers at 14-15 months of age. Those operations breed heifers at 24-26 months of age, obtaining more than $80 \%$ pregnancy rates. Because the calves are heavy and present adequate frame size at weaning, the supply of better feeding conditions, including supplements, may allow those operations to reduce age at first breeding to 14-15 months of age, yielding an additional calf during the reproductive life of cow, as already obtained in countries with very intensive beef cattle production.

Therefore, further studies to identify factors that influence age at first breeding are warranted. In addition, due to the increasing competition for land with natural pastures, traditionally used for beef cattle production, cattle breeding systems need to become more competitive, further reducing age at first breeding.

The objective of this study was to evaluate the supply of a feed supplement to grazing heifers to obtain adequate body development and backfat thickness to allow heifers to conceive at 14-15 months of age. 


\section{Material and Methods}

The experiment was carried out in Dom Pedrito, state of Rio Grande do Sul, Brazil, between June 06, 2012 and March 03, 2013. The relief is characterized as plain with low elevations. The soil is classified as eutrophic hydromorphic planosol (Embrapa, 1999) and the climate is subtropical (Moreno, 1961).

The experiment included 100 Hereford female calves derived from first-calf cows, with average weaning age of 120 days (in April, 2012), that were subjected to the typical health management practices applied on the farm. Calves had free access to a mineral supplement containing $80 \mathrm{~g}$ of phosphorus per $\mathrm{kg}$. All procedures performed in the study involving animals were in accordance with the ethical standards of the institution or practice at which the studies were conducted.

Between June 20 and August 20 (60 days), calves were kept in two 50-ha paddocks with natural pasture (NP), composed mainly of Andropogon lateralis, Desmodium incanum, Paspalum dilatatum, Paspalum notatum, and Trifolium polimorphum. Two feeding systems were applied: NP - calves grazing on natural pasture or NPs calves grazing on natural pasture and fed a supplement at $1 \%$ of their body weight (BW), corresponding to the first supplementation period. The supplement contained $14 \%$ crude protein (CP) and $72 \%$ total digestible nutrients.

From August 20 until November 02 (73 days), calves from both groups grazed together on a single 132-ha ryegrass (RG) (Lolium multiflorum Lam.) paddock and returned to a natural pasture paddock on November 03 until the beginning of the breeding season, on November 18 (late spring). On October 18, half of the heifers from each previous feeding system were randomly selected and fed the supplement until November 18. Therefore, heifers were fed or not the supplement for the last 15 days grazing on ryegrass and the 15 days upon the return to the natural pasture, corresponding to the second supplementation period. During this period, the following treatments (feeding systems) were applied between October 18 and November 18 (30 days):

NPs-RGs: heifers fed the supplement during both supplementation periods

NPs-RG: heifers fed the supplement during the first period, but not during the second period;

NP-RGs: heifers not fed the supplement during the first supplementation period and supplemented during the second supplementation period;

NP-RG: heifers not fed the supplement in either supplementation period.
Forage availability was estimated every 28 days according the comparative method of Haydock and Shaw (1975). Forage dry matter (DM) and CP contents were determined according to the methods of the AOAC (1984). Calves were weighed every 28 days after 14-h fasting to determine average daily gain (ADG).

Rib eye (longissimus muscle) area (UREA) and backfat thickness (UBFT) were determined between the 12th and the 13th rib by ultrasound (Aloka Co., LTD, model SSD500, Tokio, Japan; 3.5 MHz and 17.2-cm long linear transducer, model UST-5044) at the time animals were weighed. Images were read by a technician certified by the US Ultrasound Guidelines Council, recorded, and analyzed according the protocol of the laboratory CUPLab, UFRGS, Brazil.

Based on ultrasound examination and rectal palpation, reproductive tract score (RTS) (Anderson et al., 1991) was determined and used to estimate pubertal status and ovarian cyclicity before the breeding season, when the calves were approximately 365 days old. During the first examination, the following parameters were evaluated: uterine development (uterus depth); distance between the ventral and the dorsal walls of the uterus body immediately after the cervical ring; ovarian follicle development by measuring the diameter of the largest follicle; and the presence of corpus luteum (CL) in both ovaries. Heifers with RTS between 1 and 3 were considered immature, whereas those presenting a CL in one or both ovaries and/or follicles larger than $10 \mathrm{~mm}$ (RTS of 4 and 5) were considered as cycling females, according to Freitas et al. (2005). In the second examination (55 days before the breeding season), only the presence of CL, indicating cyclicity, was evaluated.

At the time of RTS estimation, relative pelvic area (RPA) was determined using a pelvimeter (model Rice) by transrectal route. Pelvis width was measured as the distance between the right and the left ileum, and pelvis height was measured close to the psoas tubercle and corresponded to the distance between the pubis symphysis and the base of the body of the sacral vertebrae.

At the beginning of the breeding season (from November 18, 2012 to January 31, 2013; 75 days), heifers were 420-450 days old and presented $252 \mathrm{~kg}$ average BW, which ranged between 249 and 289 as a function of feeding system. Four two-year-old Hereford bulls, previously approved by breeding soundness examination, were used for mating. Pregnancy diagnosis was performed 30 days after the end of the breeding season by ultrasound (Aloka Co., LTD, model ProSound 2, Tokio, Japan; transrectal linear transducer at $6 \mathrm{MHz}$ ). Heifers grazed as a single group on NP, with average pasture availability of $1308 \mathrm{~kg} \mathrm{DM} / \mathrm{ha}$ 
and $5.12 \% \mathrm{CP}$ per $\mathrm{kg}$, during the breeding season and until pregnancy diagnosis.

Body condition score (BCS) was visually evaluated at the beginning and at the end of the breeding season according to a $1-5$ scale $(1=$ thin and $5=$ fat $)$, as proposed by Lowman et al. (1976).

A completely randomized experimental design with measures repeated in time was applied, with two feeding systems (NPs and NP) and five measurement dates in two phases (from June 20 to August 20 and from August 20 to October 18) for the first phase of the study. Average daily weight gain data did not present normal distribution and were subjected to tangent and logarithm transformations for the first and second phases, respectively.

A completely randomized experimental design, with four feeding systems (NPs-RGs, NP-RGs, NPs-RG, and NP-RG) was applied for the data obtained in the period of October 18 to November 18. This procedure was used to compare relative pelvic area among treatments. Backfat thickness data did not present normal distribution after transformation and were analyzed by the non-parametric test of Kruskal-Wallis. A completely randomized experimental design, with four feeding systems (NPs-RGs, NP-RGs, NPs-RG, and NP-RG) and four measurement days (Nov 18/2012, Dec 18/2012, Jan 18/2013, and Jan 31/2013), was applied to analyze BW. Despite transformations, average daily gain and BCS data did not present normal distribution and were analyzed by the Kruskal-Wallis test. Three evaluation periods (Nov 18 - Dec 18/2012, Dec 18/2012 Jan 18/2013, and Jan 18 - Jan 31/2013) were considered for ADG analysis. Only initial (Nov 11, 2012) and final (Jan 31, 2013) BCS were considered for analysis. The Chisquare test was used to compare the parameters ADG, BW, UREA, UBFT, BCS, and RPA between pregnant and empty heifers, to compare pregnancy rates with RTS, and to verify the possible association between pregnancy rate (empty or pregnant) and feeding systems. Data were statistically analyzed using the MIXED procedure according to the following general mathematical model:

$$
\gamma_{\mathrm{ijk}}=\mu+\tau_{\mathrm{i}}+\mathrm{n}_{\mathrm{j} ; \mathrm{i}}+\alpha_{\mathrm{k}}+\tau \alpha_{\mathrm{ik}}+\mathrm{e}_{\mathrm{ijk}} \text {, }
$$

in which: $\gamma_{\mathrm{ijk}}$ is the dependent variable; $\mu$ is the mean of all observations; $\tau_{\mathrm{i}}$ is the fixed effect of the $i$-th feeding system; $\mathrm{n}_{\mathrm{j}, \mathrm{i}}$ is the random effect of nested heifers within feeding systems; $\alpha_{\mathrm{k}}$ is the fixed effect of the $k$-th evaluation dates; $\tau \alpha_{\mathrm{ik}}$ is the fixed effect of the interaction between the $i$-th feeding system and the $k$-th evaluation dates; and $\mathrm{e}_{\mathrm{ijk}}$ is the random residual error.

When differences were detected, means were compared by the least square means (lsmeans) test. Structure selection tests were carried out using the Bayesian information criterion to determine the model that best represented the data. A maximum significance level of 5\% was adopted for all analyses. All statistical analyses were performed using SAS (Statistical Analysis System, version 9.0) software.

\section{Results}

There was an interaction $(\mathrm{P}<0.05)$ (Table 1) between feeding systems and evaluation dates for $\mathrm{ADG}, \mathrm{BW}$, and UREA when the calves grazed on the natural pasture during the first period of the study. Calves fed the supplement presented $0.237 \pm 0.206$ and $0.041 \pm 0.197 \mathrm{~kg} / \mathrm{d}$ ADG during the first and second evaluation periods, respectively, corresponding to $67.71 \%$ and $9.95 \%$ higher ADG compared with those that did not receive supplementation. As a result, the calves fed the supplement presented $171.95 \pm 17.84$ and $173.15 \pm 17.92 \mathrm{~kg} \mathrm{BW}$ on the first and second evaluation dates, respectively. Calves in the NPs group presented UREA values of $26.23 \pm 3.16,30.42 \pm 4.75$, and $24.06 \pm 3.90 \mathrm{~cm}^{2}$ on the first, second, and third evaluation dates, respectively. These values were $8.48 \%, 22.91 \%$, and $21.82 \%$ higher than those obtained in the NP calves on those dates.

Feeding systems and measurement dates influenced UBFT. Calves fed the supplement presented higher UBFT $(0.80 \pm 0.72 \mathrm{~mm}$, on average), representing a $95.12 \%$ increase relative to those that were not supplemented. Backfat thickness was lower on the first measurement date $(0.41 \pm 0.63 \mathrm{~mm})$ compared with the third measurement date $(0.80 \pm 0.70 \mathrm{~mm})$. The average value obtained on the second measurement date $(0.61 \pm 0.75 \mathrm{~mm})$ was not statistically different from those measured on the first and third dates.

While grazing as a single group on ryegrass, ADG was affected by the interaction $(\mathrm{P}=0.0061)$ between previous FS and evaluation dates (Table 2). Calves in the NPs group presented 5\% higher ADG $(0.903 \pm 0.206 \mathrm{~kg})$ compared with those of the NP group on the first weighing date, but not on the second date. No interaction ( $\mathrm{P}=0.5098)$ between FS and weighing dates was observed for BW. Calves supplemented while grazing on natural pastures were, on average, $13.36 \%$ heavier than those not supplemented $(217.08 \pm 2.25 \mathrm{~kg})$. The lowest BW was observed on the first weighing date $(191.35 \pm 1.93 \mathrm{~kg})$, which was $11.91 \%$ lower than on the second weighing date when grazing in ryegrass. There was an interaction $(\mathrm{P}=0.0009)$ between previous FS and measuring dates during ryegrass grazing for UREA. The UREA of $32.73 \pm 3.58 \mathrm{~cm}^{2}$ and $34.42 \pm 0.55 \mathrm{~cm}^{2}$, measured on September 20 and October 18 in supplemented calves, respectively, were $18.20 \%$ and $13.33 \%$ higher than in those that were not supplemented. Previous FS influenced UBFT. 
The previously supplemented calves presented higher average UBFT $(1.43 \pm 0.67$ and $0.89 \pm 0.75 \mathrm{~mm})$ compared with those that did not receive supplementation. This parameter responded to the better nutritional level provided by ryegrass, increasing from $0.79 \pm 0.73 \mathrm{~mm}$ to $1.52 \pm 0.59 \mathrm{~mm}$ between the beginning and end of the ryegrass-grazing period $(\mathrm{P}<0.0001)$.

Between October 18 and November 18, 2012, the calves subjected to the feeding systems NPs-RGs and NP-RGs presented higher ADG $(\mathrm{P}<0.0001)$ than those

Table 1 - Average daily gain, body weight, rib eye area, and backfat thickness measured by ultrasound of female calves during the first period of natural pasture grazing according to feeding systems

\begin{tabular}{|c|c|c|c|c|c|}
\hline \multirow{2}{*}{ Evaluation date } & \multicolumn{2}{|c|}{ Feeding system } & \multirow{2}{*}{ Mean } & \multirow{2}{*}{$\mathrm{P}^{*}$} & \multirow{2}{*}{$\mathrm{P}^{* *}$} \\
\hline & $\mathrm{NP}$ & NPs & & & \\
\hline \multicolumn{6}{|c|}{ Average daily gain, $\mathrm{kg}$} \\
\hline Jun 20-Jul 20 & $-0.350 \pm 0.197 \mathrm{~b}$ & $0.237 \pm 0.206 \mathrm{a}$ & $-0.056 \pm 0.357$ & $<0.0001$ & 0.0182 \\
\hline Jul 20-Aug 20 & $-0.412 \pm 0.184 b$ & $0.041 \pm 0.197 \mathrm{a}$ & $-0.185 \pm 0.296$ & & \\
\hline Mean & $-0.381 \pm 0.192$ & $0.139 \pm 0.223$ & & $<0.0002$ & \\
\hline \multicolumn{6}{|c|}{ Body weight, kg } \\
\hline Jun 20 & $171.36 \pm 16.82$ & $165.55 \pm 16.63$ & $168.46 \pm 16.89$ & & \\
\hline Jul 20 & $161.92 \pm 15.60 \mathrm{~b}$ & $171.95 \pm 17.84 \mathrm{a}$ & $166.94 \pm 17.42$ & 0.0062 & $<0.0001$ \\
\hline Aug 20 & $149.97 \pm 15.40 b$ & $173.15 \pm 17.92 \mathrm{a}$ & $161.56 \pm 20.30$ & & \\
\hline Mean & $161.08 \pm 18.11$ & $170.22 \pm 17.68$ & & $<0.0001$ & \\
\hline \multicolumn{6}{|c|}{ Rib eye area, $\mathrm{cm}^{2}$} \\
\hline Jun 20 & $24.18 \pm 3.46 b$ & $26.23 \pm 3.16 \mathrm{a}$ & $25.21 \pm 3.46$ & & \\
\hline Jul 20 & $24.75 \pm 3.93 b$ & $30.42 \pm 4.75 \mathrm{a}$ & $27.59 \pm 5.19$ & $<0.0001$ & 0.0009 \\
\hline Aug 20 & $19.75 \pm 4.02 b$ & $24.06 \pm 3.90 \mathrm{a}$ & $21.90 \pm 4.50$ & & \\
\hline Mean & $22.89 \pm 4.40$ & $26.90 \pm 4.77$ & & $<0.0001$ & \\
\hline \multicolumn{6}{|c|}{ Backfat thickness, $\mathrm{mm} * * *$} \\
\hline Jun 20 & $0.23 \pm 0.49$ & $0.58 \pm 0.71$ & $0.41 \pm 0.63 b$ & & - \\
\hline Jul 20 & $0.36 \pm 0.59$ & $0.87 \pm 0.81$ & $0.61 \pm 0.75 \mathrm{ab}$ & $<0.0001$ & \\
\hline Aug 20 & $0.64 \pm 0.76$ & $0.96 \pm 0.59$ & $0.80 \pm 0.70 \mathrm{a}$ & & \\
\hline Mean & $0.41 \pm 0.64 b$ & $0.80 \pm 0.72 \mathrm{a}$ & & $<0.0001$ & \\
\hline
\end{tabular}

NP - natural pasture; NPs - natural pasture with supplement.

Means followed by different letters in the same row and in the same column are different by Tukey's test.

* Probability of the effects of evaluation dates and feeding systems.

** Probability of the interaction between evaluation dates and feeding systems.

*** Means followed by different letters in the same row and in the same column are different by Bonferroni's test.

Table 2 - Average daily gain, body weight, rib eye area, and backfat thickness measured by ultrasound of female calves during the period of ryegrass grazing as a single group

\begin{tabular}{|c|c|c|c|c|c|}
\hline \multirow{2}{*}{ Evaluation date } & \multicolumn{2}{|c|}{ Feeding system } & \multirow{2}{*}{ Mean } & \multirow{2}{*}{$\mathrm{P} *$} & \multirow{2}{*}{$\mathrm{P}^{* *}$} \\
\hline & NP & NPs & & & \\
\hline \multicolumn{6}{|c|}{ Average daily gain, $\mathrm{kg}$} \\
\hline Aug 20-Sep 20 & $0.860 \pm 0.225 b$ & $0.903 \pm 0.206 \mathrm{a}$ & $0.854 \pm 0.191$ & 0.0038 & 0.0061 \\
\hline Sep 20-Oct 18 & $0.801 \pm 0.295$ & $0.726 \pm 0.176$ & $0.764 \pm 0.245$ & & \\
\hline Mean & $0.804 \pm 0.261$ & $0.815 \pm 0.180$ & & 0.7180 & \\
\hline \multicolumn{6}{|c|}{ Body weight, kg } \\
\hline Sep 20 & $178.18 \pm 18.09$ & $204.75 \pm 19.44$ & $191.35 \pm 1.93 b$ & $<0.0001$ & 0.5098 \\
\hline Oct 18 & $205.42 \pm 19.84$ & $229.45 \pm 20.01$ & $217.23 \pm 1.93 a$ & & \\
\hline Mean & $191.49 \pm 2.24 b$ & $217.08 \pm 2.25 \mathrm{a}$ & & $<0.0001$ & \\
\hline \multicolumn{6}{|c|}{ Rib eye area, $\mathrm{cm}^{2}$} \\
\hline Sep 20 & $27.69 \pm 3.78 b$ & $32.73 \pm 3.58 \mathrm{a}$ & $30.21 \pm 4.45$ & $<0.0001$ & 0.0009 \\
\hline Oct 18 & $30.37 \pm 4.13 b$ & $34.42 \pm 0.55 \mathrm{a}$ & $32.40 \pm 4.18$ & & \\
\hline Mean & $25.35 \pm 5.25$ & $29.57 \pm 5.39$ & & $<0.0001$ & \\
\hline \multicolumn{6}{|c|}{ Backfat thickness, $\mathrm{mm}^{* * *}$} \\
\hline Sep 20 & $0.47 \pm 0.67$ & $1.12 \pm 0.64$ & $0.79 \pm 0.73 b$ & $<0.0001$ & - \\
\hline Oct 18 & $1.31 \pm 0.57$ & $1.74 \pm 0.55$ & $1.52 \pm 0.59 \mathrm{a}$ & & \\
\hline Mean & $0.89 \pm 0.75 b$ & $1.43 \pm 0.67 \mathrm{a}$ & & $<0.0001$ & \\
\hline
\end{tabular}

NP - natural pasture; NPs - natural pasture with supplement.

Means followed by different letters in the same row and in the same column are different by Tukey's test.

* Probability of the effects of evaluation dates and feeding systems.

** Probability of the interaction between evaluation dates and feeding systems.

*** Means followed by different letters in the same row and in the same column are different by Bonferroni's test. 
in the NPs-RG and NP-RG groups (Table 3). Relative to rib eye area, NPs-RGs calves presented higher values compared with NP-RGs and NP-RG calves $(\mathrm{P}<0.0021)$, while the values obtained in the NPs-RG calves were not statistically different from the other groups. Calves in the NPs-RGs group presented higher UBFT values than those in the NPs-RG and NP-RG groups $(\mathrm{P}<0.0021)$ and the values obtained in the NP-RGs group were statistically similar to the other groups.

During the breeding season, previous feeding systems did not influence ADG $(\mathrm{P}=0.1043)$, which was $0.366 \pm 0.441 \mathrm{~kg}$, on average (Table 4). However, weight gain variations were observed during the breeding season as a function of weighing date. Body condition score increased $(\mathrm{P}<0.0001)$ with NPs-RGs and NP-RGs, presenting higher scores compared with NPs-RG and NPRG heifers (Table 4). As there were no differences in ADG during the breeding season, heifers maintained the previous BW differences during this period.

Body weight was influenced by the interaction of FS with evaluation dates $(\mathrm{P}<0.0001)$ (Table 5). In the beginning of the breeding season, NPs-RGs heifers were heavier than NP-RGs and NP-RG heifers, but statistically similar to NPs-RG heifers, while NP-RG heifers were the lightest, but their BW was statistically similar to that of NP-RGs heifers. On the second and third weighing dates of the breeding season, NPs-RGs heifers continued as the heaviest. At the end of the breeding season (January 31, 2013), the statistical differences in BW among feeding systems were the same as that observed in the beginning of the breeding season.

The relative pelvic area of NPs-RGs $\left(106.41 \pm 11.92 \mathrm{~cm}^{2}\right)$ and NPs-RG $\left(107.07 \pm 12.52 \mathrm{~cm}^{2}\right)$ heifers were larger $(\mathrm{P}<0.05)$ compared with NP-RGs heifers $\left(93.74 \pm 11.76 \mathrm{~cm}^{2}\right)$;

Table 3 - Average daily gain, rib eye area, and backfat thickness measured by ultrasound measured of heifers during the last 15 days of ryegrass grazing and the first 15 days upon returning to natural pasture according to feeding systems

\begin{tabular}{|c|c|c|c|c|c|}
\hline \multirow{2}{*}{ Evaluation date } & \multicolumn{4}{|c|}{ Feeding system } & \multirow{2}{*}{$\mathrm{P}^{*}$} \\
\hline & NPs-RGs & NP-RGs & NPs-RG & NP-RG & \\
\hline & Mean \pm SD & Mean \pm SD & Mean \pm SD & Mean \pm SD & \\
\hline $\begin{array}{l}\text { ADG, } \mathrm{kg} \\
\text { Oct } 18 \text {-Nov } 18\end{array}$ & $1.418 \pm 0.061 \mathrm{a}$ & $1.512 \pm 0.068 \mathrm{a}$ & $0.985 \pm 0.070 \mathrm{~b}$ & $1.007 \pm 0.063 b$ & $<0.0001$ \\
\hline $\begin{array}{l}\text { UREA, } \mathrm{cm}^{2} \\
\text { Nov } 18\end{array}$ & $40.51 \pm 0.81 \mathrm{a}$ & $36.36 \pm 0.89 b$ & $38.44 \pm 0.92 \mathrm{ab}$ & $36.64 \pm 0.83 \mathrm{~b}$ & 0.0021 \\
\hline
\end{tabular}

ADG - average daily gain; NP - natural pasture; NPs - natural pasture with supplement; RG - ryegrass; RGs - ryegrass with supplement; SD - standard deviation; UREA - rib eye area; UBFT - backfat thickness.

Means followed by different letters in the same row are different by the least square means test.

* Probability of the effects of feeding systems.

** Means followed by different letters in the same row and in the same column are different by Bonferroni's test.

Table 4 - Average daily gain and body condition score of heifers during the breeding season, according to previous feeding systems

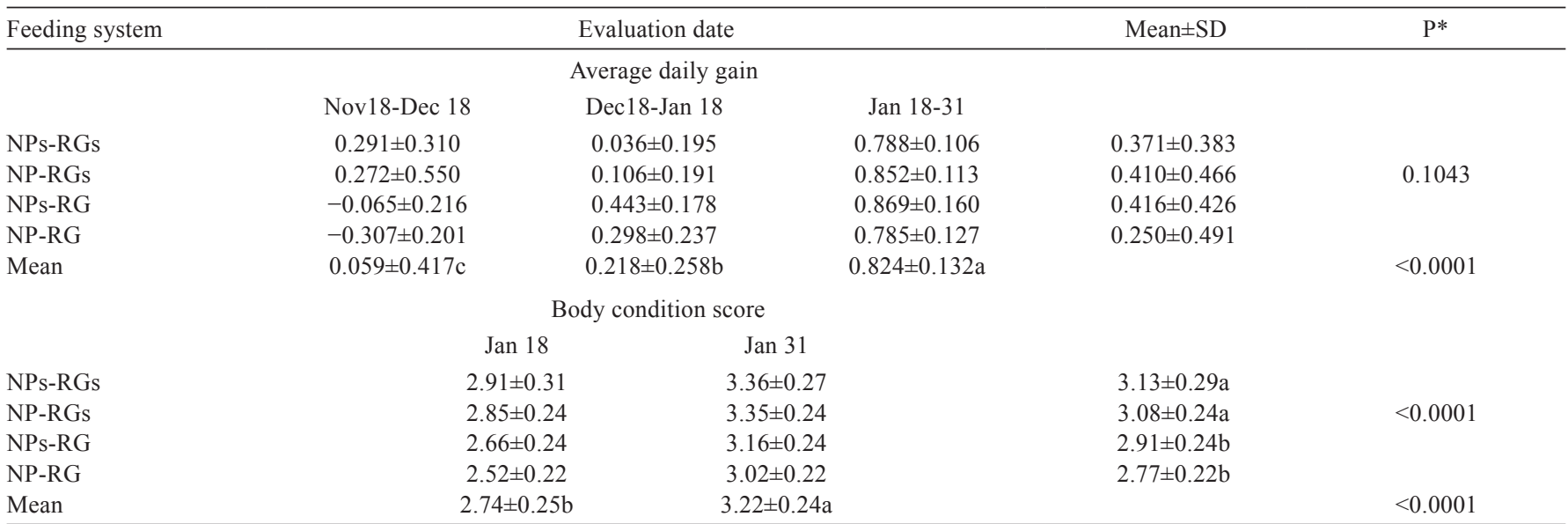

NP - natural pasture; NPs - natural pasture with supplement; RG - ryegrass; RGs - ryegrass with supplement; SD - standard deviation.

Means followed by different letters in the same row and in the same column are different by the least square means test.

* Probability of the effects of evaluation dates and feeding systems.

a,b - Means followed by different letters in the same row and in the same column are different by Bonferroni's test. 
however, the RPA of NP-RG heifers (100.34 \pm 14.07$)$ was statistically similar to that of all the other groups (Table 6). The highest percentage of pubertal heifers (with RTS $>3$ ) was determined in the NPs-RG group (34.3\%). When heifers were classified according to RTS (Table 6), 65 were immature and 35 reached puberty, out of which $62.9 \%$ conceived by the end of the breeding season.

The presence of CL in one of the ovaries was detected in $17.8 \%$ of the heifers that became pregnant and in $5.1 \%$ of those that did not conceive. Heifers in the NPs-RGs presented a $47 \%(n=21)$ pregnancy rate; NPs-RG heifers, $22 \%(\mathrm{n}=10)$; NP-RGs heifers, 18\% $(\mathrm{n}=8)$; and NP-RG heifers, $13 \%(n=6)(P=0.001)$ (Table 6).

Pregnant heifers were those that presented higher ADG between October 18 and November 18 of 2012, larger RPA, and higher BW and BCS in the beginning and end of the breeding season (Table 7); however, their ADG, UREA, and UBFT, determined during the breeding season, were not different compared with the non-pregnant heifers.

Table 5 - Body weight of heifers during the breeding season according to previous feeding systems

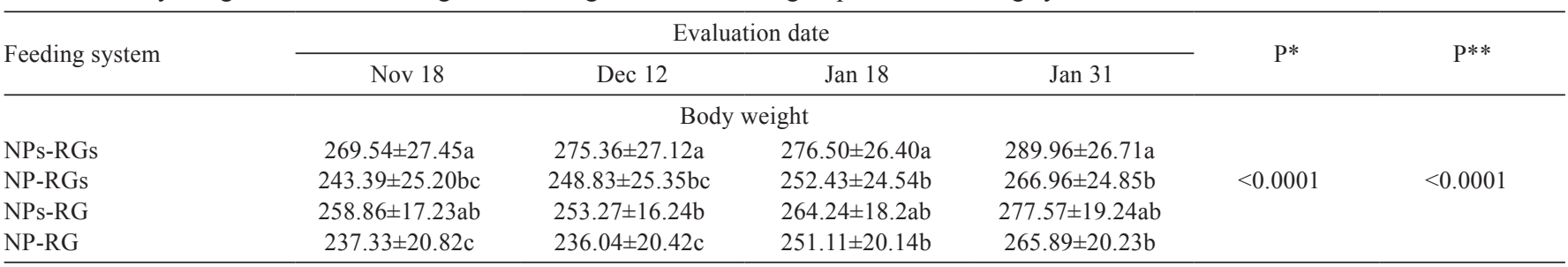

NP - natural pasture; NPs - natural pasture with supplement; RG - ryegrass; RGs - ryegrass with supplement.

Means followed by different letters in the same row and in the same column are different by the least square means test.

* Probability of the effects of evaluation dates and feeding systems.

** Probability of the interaction between evaluation dates and feeding systems.

Table 6 - Relative pelvic area, reproductive tract score classification of 365-day-old heifers, and pregnancy rate according to the feeding systems

\begin{tabular}{|c|c|c|c|c|c|c|}
\hline & \multirow{2}{*}{$\mathrm{n}$} & \multicolumn{4}{|c|}{ Feeding system } & \multirow{2}{*}{ Preg $^{1}$} \\
\hline & & NPs-RGs & NP-RGs & NPs-RG & NP-RG & \\
\hline Relative pelvic area, $\mathrm{cm}^{2}$ & & $106.41 \pm 11.92 \mathrm{a}$ & $93.74 \pm 11.76 b$ & $107.07 \pm 12.52 \mathrm{a}$ & $100.34 \pm 14.07 \mathrm{ab}$ & \\
\hline Reproductive tract score $<3$ & 55 & $14(25.5 \%)$ & $17(30.9 \%)$ & $8(14.5 \%)$ & $16(29.1 \%)$ & $34.5 b$ \\
\hline Reproductive tract score $=3$ & 10 & $3(30.0 \%)$ & $4(40.0 \%)$ & $2(20.0 \%)$ & $1(10.0 \%)$ & $40.0 \mathrm{~b}$ \\
\hline Reproductive tract score $>3$ & 35 & $11(31.4 \%)$ & $2(5.7 \%)$ & $12(34.3 \%)$ & $10(28.6 \%)$ & $62.9 \mathrm{a}$ \\
\hline Preg $^{1}$ & & $47 \%$ & $18 \%$ & $22 \%$ & $13 \%$ & \\
\hline
\end{tabular}

NP - natural pasture; NPs - natural pasture with supplement; RG - ryegrass; RGs - ryegrass with supplement.

$\mathrm{a}, \mathrm{b}$ - Means followed by the different letters in the same row are different by Tukey's test $(\mathrm{P}<0.05)$.

${ }^{1}$ Pregnancy rate $(\%)$.

Table 7 - Average daily gain, body weight, rib eye area, backfat thickness measured by ultrasound, body condition score, and relative pelvic area of pregnant and non-pregnant heifers

\begin{tabular}{|c|c|c|c|}
\hline \multirow[b]{2}{*}{ Evaluation date } & \multicolumn{2}{|c|}{ Group } & \multirow[b]{2}{*}{ P-value } \\
\hline & $\begin{array}{c}\text { Pregnant } \\
\text { Mean } \pm \text { SD }\end{array}$ & $\begin{array}{c}\text { Non-pregnant } \\
\text { Mean } \pm \text { SD }\end{array}$ & \\
\hline Avergage daily gain Oct 18 -Nov $18, \mathrm{~kg}$ & $1.370 \pm 0.416 \mathrm{a}$ & $1.162 \pm 0.385 b$ & 0.0110 \\
\hline Avergage daily gain Nov $18-\mathrm{Jan} 31, \mathrm{~kg}$ & $0.822 \pm 0.109$ & $0.826 \pm 0.150$ & 0.9035 \\
\hline Body weight Nov $18, \mathrm{~kg}$ & $261.38 \pm 25.99 \mathrm{a}$ & $245.42 \pm 24.55 b$ & 0.0022 \\
\hline Body weight Jan $31, \mathrm{~kg}$ & $283.39 \pm 25.11 \mathrm{a}$ & $268.37 \pm 22.72 b$ & 0.0017 \\
\hline Rib eye area Nov $18, \mathrm{~cm}^{2}$ & $38.75 \pm 4.21$ & $37.43 \pm 4.77$ & 0.1486 \\
\hline Backfat thickness Nov $18, \mathrm{~mm}$ & $2.39 \pm 0.65$ & $2.22 \pm 0.72$ & 0.3335 \\
\hline Body condition score Nov $18^{*}$ & $2.84 \pm 0.30 \mathrm{a}$ & $2.65 \pm 0.27 b$ & 0.0007 \\
\hline Body condition score Jan $31 *$ & $3.31 \pm 0.27 \mathrm{a}$ & $3.15 \pm 0.27 b$ & 0.0021 \\
\hline Relative pelvic area \pm 365 days, $\mathrm{cm}^{2}$ & $106.38 \pm 12.52 \mathrm{a}$ & $98.42 \pm 13.35 b$ & 0.0031 \\
\hline
\end{tabular}

SD - standard deviation.

Means followed by different letters in the same row are different by Tukey's test.

* Means followed by different letters in the same row and in the same column are different by Bonferroni's test. 


\section{Discussion}

The low average dry matter (DM) availability of the NP, of $1277 \mathrm{~kg} / \mathrm{ha}$ during the first feeding period (June 20 to August 20), caused a BW loss of $22 \mathrm{~kg}$ (from 171 to $149 \mathrm{~kg}$ ) in the heifers grazing on natural pasture and not fed the supplement (Table 1). Despite presenting higher ADG at the end of the first month of the experiment compared with the non-supplemented group, the ADG of the supplemented heifers was almost nil in the second month due to the low DM availability and $\mathrm{CP}$ content $(5.7 \%)$ of the pasture, indicating that the supplement provided only their maintenance requirements. The low precipitation levels of January (23 mm), March (31 mm), and May $(8 \mathrm{~mm})$ of 2012 prevented DM accumulation in the NP and therefore, did not allow the supplemented heifers to achieve better performance and the non-supplemented heifers to maintain their BW. Although the low DM availability limited the performance of the supplemented heifers due to reduced DM intake (Horn et al., 2005), their performance was better compared with those that were not fed the supplement. This is due to the possible positive association between the supplement and the pasture, which is most frequently observed when pasture nutrients limit ruminal fermentation (Dixon and Stockdale, 1999).

During the first month on ryegrass (Table 2), heifers that were previously supplemented presented higher ADG. Supplemented cattle consume higher DM levels because of the additive effect of supplement intake on pasture intake (Beever and Thorp, 1997). However, there were no differences in ADG $(0.809 \pm 0.224 \mathrm{~kg}$, on average) between September 20 and October 18 . The average DM availability of $1273 \mathrm{~kg} / \mathrm{ha}$ and the $11.30 \% \mathrm{CP}$ content obtained in the ryegrass pasture is consistent with the recommendations of $1200-1600 \mathrm{~kg} / \mathrm{ha}$ of Mott (1984) and Pilau and Lobato (2005) to prevent intake restriction.

There was an effect of supplementation on the evolution of UREA between June 06 and October 18 and on UBFT relative to the average values obtained at the end of each feeding period (NP and RG in a single group) (Tables 1 and 2). Heifers grazing on natural pastures fed supplement presented $4.05 \pm 3.58 \mathrm{~cm}^{2}$ and $0.43 \pm 0.08 \mathrm{~mm}$ higher UREA and UBFT values, respectively, on October 18, compared with the non-supplemented heifers. These results are in agreement with the findings of Roberts et al. (2009), who also observed that feed restriction reduced the UREA $\left(4.70 \mathrm{~cm}^{2}\right)$ and UBFT $(0.68 \mathrm{~mm})$ values of nonsupplemented heifers relative to supplemented heifers. The supplementation of heifers grazing on both natural pasture and on ryegrass promoted better muscling (Tables 2 and 3 ), represented by rib eye area (UREA). According to Berg and Butterfield (1976), the longissimus muscle is the muscle that presents the highest growth rate during this period.

The strongest effect on UBFT was obtained when heifers were supplemented during the last 15 days of ryegrass grazing. Heifers supplemented during the final periods of each feeding system (NPs-RGs and NP-RGs) accumulated more fat while grazing on ryegrass than those not supplemented (NP-RG) or tended to have thicker backfat than those supplemented only while grazing on natural pasture (NPs-RG). The results show that backfat thickness (Table 3) changed when heifers were supplemented at the beginning or at the end of the period (NPs-RG or NP-RGs).

According to Pötter et al. (2010), feeding concentrate supplements to female beef calves increases their individual weight gain and may explain the weight gain of the NPs-RG and NP-RG heifers during the period of October 18 and November 18, 2012. The highest UREA was observed in heifers supplemented while grazing on natural pasture (NPs-RGs and NPs-RG). During the same period, these same heifers presented higher UBFT because supplementation allows to accumulate more fat than those maintained exclusively on pasture (Frizzo et al., 2003).

During the breeding season, the low average daily gains observed (Table 4), despite being different among evaluation dates $(\mathrm{P}<0.05)$, may be explained by the low precipitation recorded between November 2012 and January 2013 (monthly average of $54 \mathrm{~mm}$ ), which, again, dramatically reduced natural pasture allowance.

Menegaz et al. (2008) obtained significantly different $(\mathrm{P}<0.05)$ average $\mathrm{BW}$ of $302.8,317.8$, and $330.7 \mathrm{~kg}$ in heifers grazing on natural pasture, natural pasture + supplementation, and improved natural pasture, respectively, at the beginning of the breeding season. Those authors considered these BW were adequate to provide good reproductive results. The NRC (1996) recommends a target BW of $60 \%$ mature cow weight at the beginning of the breeding season to obtain high reproduction rates. However, studies carried out in the last decades comparing intensive with extensive systems found that lower target weights $(50-57 \%$ of the mature weight) reduce production costs and do not negatively affect reproductive performance (Funston and Deutscher, 2004; Roberts et al., 2009; Funston and Larson, 2011; Mulliniks et al., 2013). Considering that the geographical region of the farm and the applied production system do not allow for heavy mature and weaning weights, heifers need to achieve a higher percentage of the mature weight of a cow to reach puberty. In this herd, a mature cow weight of $500 \mathrm{~kg}$ is used as reference to obtain adequate reproduction indices, and 
therefore, heifers should start breeding with approximately $300 \mathrm{~kg} \mathrm{BW}$ and subsequently present adequate weight gain for growing heifers. However, the average BW at the beginning of breeding season of NPs-RGs, NP-RGs, NPs$\mathrm{RG}$, and NP-RG heifers corresponded to $54 \%, 49 \%, 52 \%$, and $47 \%$ of mature cow weight, respectively, and gained $20,24,19$, and $29 \mathrm{~kg}$ during the 75 days of the breeding season. At the end of the breeding season, their BW was still below the $60 \%$ mature weight required to start breeding and the body weights of NPs-RGs, NP-RGs, NPs-RG, and NP-RG heifers corresponded to $58 \%, 53 \%, 56 \%$, and $53 \%$ of mature weight, respectively. Those fed the supplement while grazing on natural pasture between June 20 and August 20 presented higher BW due to their higher ADG during that period compared with the non-supplemented heifers. On the other hand, at the beginning and end of the breeding season, the BCS of NPs-RGs and NP-RGs heifers, which were supplemented during the last 15 days on ryegrass and the first 15 days upon returning to natural pasture, was higher than that of NPs-RG and NP-RG heifers that were not supplemented during these periods (3.13 and 3.08 vs 2.91 and 2.77). Those scores were higher than the minimum score recommended by Anderson et al. (1991).

The higher percentages of NPs-RG and NPs-RGs heifers that achieved puberty (RTS $>3$ ) (Table 6) demonstrate the need of energy supplementation to achieve the required BW and RTS (Gasser et al., 2006).

Follicle dynamics can already be detected in eightmonth-old calves; however, few changes are evidenced until the first ovulation (Adams et al., 1994; Evans et al., 1994). In heifers fed adequate nutritional levels during the pre-pubertal period, the luteinizing hormone, responsible for ovulation, starts to increase gradually four months before puberty (Swanson et al., 1972; Day et al., 1986). Therefore, the body weight maintenance or loss observed in the present experiment during the first grazing period (Table 1) probably determined the low percentage of heifers with RTS $>3$ and, consequently, their low pregnancy rates (Table 6). The production of the gonadotropins required for follicle recruitment and, consequently, ovarian activity, is negatively affected in heifers subjected to nutritional restriction to maintenance levels, i.e., when there is no weight gain (Henricks et al., 1986; Murphy et al., 1991).

The presence of $\mathrm{CL}$ in one of the ovaries, as evaluated 55 days before the beginning of the breeding season, was detected in $17.8 \%$ of the heifers that conceived and in $5.1 \%$ of those that failed to conceive. This indicates a higher proportion of heifers that conceived had previously achieved sexual maturity, increasing the probability of reproductive success. Heifers with RTS $>3$ and average BW of $264.08 \pm 29.00 \mathrm{~kg}$, which corresponded to $52.82 \%$ of mature cow weight, presented $62.9 \%$ pregnancy rate (Table 6). High RTS at the beginning of the breeding season is positively associated with pregnancy rate, weaning weight, repeated pregnancy rate, and longevity in the herd (Holm et al., 2009). These authors also state that RTS is the best predictor of heifer fertility and that age has a stronger effect on RTS than BW and BCS. Vaz and Lobato (2010), evaluating conception rates of 13- to 15-month-old heifers, obtained $94.74 \%$ pregnancy rates in heifers heavier than $305 \mathrm{~kg}$ at the beginning of the breeding season and $58.0 \%$ in heifers weighing $261-275 \mathrm{~kg}$. The pregnancy rate obtained in the present study was similar to that obtained in the lightest heifers by Vaz and Lobato (2010).

The pregnancy rates were low, including the $47 \%$ rate of the NPs-RGs heifers, considering the objective of anticipating breeding age in one year. The observed growth and reproduction indices of the heifers in this study show that higher weaning weight and higher ADG are required, as well as more intensive selection for sexual precocity. Beef cattle production systems using supplementation need more flexibility to compensate for the wide variation of dry matter availability in natural pastures as a result of the climate variability recorded in the subtropical regions of Brazil, as observed in the present study. Supplements should be offered according to specific situations experienced by each herd and environment. Heifers grazing on winter-spring pastures require high forage allowance to gain sufficient weight or possibly high levels of supplemental feed to achieve their target BW, and consequently, to express their reproductive genetic potential (Bargo et al., 2003). In this study, feeding the supplement was beneficial when natural pasture allowance was limiting at the beginning of winter, when heifers returned to the natural pasture in November, and even when grazing on ryegrass in the end of its cycle. Rocha and Lobato (2002) obtained a 0.429 ADG by supplementing heifers grazing on natural pasture at an allowance of $900 \mathrm{~kg} \mathrm{DM} / \mathrm{ha}$ during autumn. Pilau and Lobato (2005) recorded $0.513 \mathrm{~kg} / \mathrm{d}$ ADG in calves fed a supplement while grazing on ryegrass at the end of its cycle and $0.260 \mathrm{~kg} / \mathrm{d}$ in those that exclusively grazed ryegrass.

The heifers that conceived were those that had higher ADG before the breeding season, were heavier, and had better BCS both at the beginning and end of the breeding season, and larger relative pelvic area around 365 days of age (Table 7). Rocha and Lobato (2002) also verified higher pregnancy rates in heifers with heavier weaning weights, 
better phenotype (frame, precocity, and muscling), heavier body weight, and better BCS at the beginning and end of the breeding season. Therefore, it is suggested that only the heaviest female calves at weaning should be used to reduce the weight gain required when breeding heifers at 14-15 months of age.

\section{Conclusions}

The supply of a feed supplement to heifers grazing on natural pasture after the weaning is necessary to obtain better body development and sexual maturity at the beginning of the breeding season. The obtained pregnancy rates indicate that feeding systems with higher pasture allowance and higher supplement levels than those evaluated in the present study are required to achieve better calf development after weaning and better reproduction indices when aiming at breeding heifers at 14-15 months of age.

\section{Acknowledgments}

This study was financed by Coordenação de Aperfeiçoamento de Pessoal de Nível Superior (CAPES).

\section{References}

Adams, G. P.; Evans, A. C. O. and Rawlings, N. C. 1994. Follicular waves and circulating gonadotrophins in 8-month-old prepubertal heifers. The Journal of the Society for Reproduction and Fertility 1:27-33.

Anderson, K. J.; Lefever, D. G.; Brinks, J. S. and Odde, K. G. 1991. The use of reproductive tract scoring in beef heifers. Agri-Practice 12:19-26.

AOAC - Association of Official Analytical Chemists. 1984. Officials methods of analysis. [s.n.], Washington, D.C., USA.

Bargo, F.; Muller, L. D.; Kolver, E. S. and Delahoy, J. E. 2003. Invited review: Production and digestion of supplemented dairy cows on pasture. Journal of Dairy Science 86:1-42.

Beever, D. E. and Thorp, C. L. 1997. Supplementation of forage diets. p.419. In: Milk composition, production and biotechnology. CAB International, Oxon.

Beretta, V.; Lobato, J. F. P. and Mielitz Netto, C. G. A. 2001. Produtividade e eficiência biológica de sistemas pecuários de cria diferindo na idade das novilhas ao primeiro parto e na taxa de natalidade do rebanho do Rio Grande do Sul. Revista Brasileira de Zootecnia 30:1278-1286.

Berg, R. T. and Butterfield, R. M. 1976. New concepts of cattle growth. Sydney University Press, Sydney, Australia.

Brasil. Ministério da Agricultura, Pecuária e Abastecimento. 2013. Projeções do agronegócio: Brasil 2012/2013 a 2022/2023. Ministério da Agricultura, Pecuária e Abastecimento. Assessoria de Gestão Estratégica. Mapa/ACS, Brasília.

Day, M. L.; Imakawa, K.; Zalesky, D. D.; Kittok, R. J. and Kinder, J. E. 1986. Effects of restriction of dietary energy intake during the prepubertal period on secretion of luteinizing hormone and responsiveness of the pituitary to luteinizing hormone-releasing hormone in heifers. Journal of Animal Science 62:1641-1648.

Dixon, R. M. and Stockdale, C. R. 1999. Associative effects between forages and grains: consequences for feed utilization. Australian Journal of Agricultural Research 50:757-774.

Embrapa - Empresa Brasileira de Pesquisa Agropecuária. 1999. Sistema brasileiro de classificação de solos. Embrapa, Brasília.

Evans, A. C. O.; Adams, G. P. and Rawlings, N. C. 1994. Endocrine and ovarian follicular changes leading up to the first ovulation in prepubertal heifers. The Journal of the Society for Reproduction and Fertility 100:187-194.

Frizzo, A.; Rocha, M. G.; Restle, J.; Freitas, M. R.; Biscaíno, G. and Pilau, A. 2003. Produção de forragem e retorno econômico da pastagem de aveia e azevém sob pastejo com bezerras de corte submetidas a níveis de suplementação energética. Revista Brasileira de Zootecnia 32:632-642.

Funston, R. N. and Larson, D. M. 2011. Heifer development system: Dry-lot feeding compared with grazing dormant winter forage. Journal of Animal Science 89:1595-1602.

Funston, R. N. and Deutscher, G. H. 2004. Comparison of target breeding weight and breeding date for replacement beef heifers and affects on subsequent reproduction and cal performance. Journal of Animal Science 82:3094-3099.

Gasser, C. L.; Grum, D. E.; Mussard, M. L.; Fluharty, F. L., Kinder, J. E. and Day, M. L. 2006. Induction of precocious puberty in heifers I: Enhanced secretion of luteinizing hormone. Journal of Animal Science 84:2035-2041.

Haydock, K. P. and Shaw, N. H. 1975. The comparative yield method for estimating dry mather yield of pasture. Australian Journal of Experimental Agriculture and Animal Husbandry 15:663-670.

Henricks, D. M.; Rone, J. D.; Ferrell, C. L. and Echternkamp, S. E. 1986. A note on the effect of nutrition on ovulation and ovarian follicular populations in the individually fed post-partum beef heifer. Animal Production 43:557-560.

Holm, D. E.; Thompson, P. N. and Irons, P. C. 2009. The value of reproductive tract scoring as a predictor of fertility and production outcomes in beef heifers. Journal of Animal Science 87:1934-1940.

Horn, G. W.; Beck, P. A.; Andrae, J. G. and Paisley, S. I. 2005. Designing supplements for stocker cattle grazing wheat pasture. Journal of Animal Science 83:E69-E78.

Lowman, B. G.; Scott, N. and Somerville, S. 1976. Condition scoring beef cattle. Bulletin, 6. East of Scotland College of Agriculture, Edinburgh.

Moreno, J. A. 1961. Clima do Rio Grande do Sul. Secretaria da Agricultura, Porto Alegre.

Menegaz, A. L.; Lobato, J. F. P. and Pereira, A. C. G. 2008. Influência do manejo alimentar no ganho de peso e no desempenho reprodutivo de novilhas de corte. Revista Brasileira de Zootecnia $37: 1844-1852$.

Mott, G. O. 1984. Relationship of available forage and animal performance in tropical grazing systems. p.373-377. In: Proceedings of the Forage Grassland Conference, Houston. American Forage and Grassland Council, Lexington.

Mulliniks, J. T.; Hawkins, D. E.; Kane, K. K.; Cox, S. H.; Torell, L. A.; Scholljegerdes, E. J. and Petersen, M. K. 2013. Metabolizable protein supply while grazing dormant winter forage during heifer development alters pregnancy and subsequent in-herd retention rate. Journal of Animal Science 91:1409-1416

Murphy, M. G.; Enright, W. J.; Crowe, M. A.; McConnell, K.; Spicer, L. J.; Boland, M. P. and Roche, J. F. 1991. Effect of dietary-intake on pattern of growth of dominant follicles during the estrous-cycle in beef heifers. Journal of Reproduction and Fertility 92:333-338.

NRC - National Research Council. 1996. Nutrient requirement of beef cattle. 7th ed.: National Academy Press, Washington, D.C. 
Pilau, A. and Lobato, J. F. P. 2005. Recria de bezerras com suplementação no outono e pastagem cultivada no inverno. Revista Brasileira de Zootecnia 35:2388-2396.

Pötter, L.; Rocha, M. G.; Roso, D.; Costa, V. G.; Glienke, C. L. and Rosa, A. N. 2010. Suplementação com concentrado para novilhas de corte mantidas em pastagens cultivadas de estação fria. Revista Brasileira de Zootecnia 39:992-1001.

Pötter, L.; Lobato, J. F. P. and Mielitz Netto, C. G. A. 1998. Produtividade de um modelo de produção para novilhas de corte primíparas aos dois, três e quatro anos de idade. Revista Brasileira de Zootecnia 27:613-619.

Roberts, A. J.; Geary, T. W.; Grings, E. E.; Waterman, R. C. and MacNeil, M. D. 2009. Reproductive performance of heifers offered ad libitum or restricted access to feed for a one hundred forty-day period after weaning. Journal of Animal Science 87:3043-3052

Rocha, M. G. and Lobato, J. F. P. 2002. Sistemas de alimentação pósdesmama de bezerras de corte para acasalamento com 14/15 meses de idade. Revista Brasileira de Zootecnia 31:1814-1822.

Swanson, L.V.; Hafs, H. D. and Morow, D. A. 1972. Ovarian characteristics and serum $\mathrm{LH}$, prolactin, progesterone and glucocorticoid from first estrus to breeding size in Holstein heifers. Journal of Animal Science 34:284-293.

Vaz, R. Z. and Lobato, J. F. P. 2010. Efeito da idade do desmame no desenvolvimento de novilhas de corte até os 14/15 meses de idade. Revista Brasileira de Zootecnia 39:289-298. 